\title{
PARTIAL PERCEPTION AND APPROXIMATE UNDERSTANDING $^{1}$
}

\author{
BARBARA LEWANDOWSKA-TOMASZCZYK \\ State University of Applied Sciences in Konin \\ barbara.lewandowska.tomaszczyk@gmail.com
}

\begin{abstract}
What is discussed in the present paper is the assumption concerning a human narrowed sense of perception of external world and, resulting from this, a basically approximate nature of concepts that are to portray it. Apart from the perceptual vagueness, other types of vagueness are also discussed, involving both the nature of things, indeterminacy of linguistic expressions and psycho-sociological conditioning of discourse actions in one language and in translational contexts. The second part of the paper discusses the concept of conceptual and linguistic resemblance (similarity, equivalence) and discourse approximating strategies and proposes a Resemblance Matrix, presenting ways used to narrow the approximation gap between the interacting parties in monolingual and translational discourses.
\end{abstract}

Keywords: almost resemblance, approximating strategies, Cluster Equivalence, collocations, corpus data, displacement of senses, meaning approximation, more-or-less resemblance, re-conceptualization (reconceptualization), Resemblance Matrix, tolerance threshold, vagueness

\section{Introduction: World models and the real world}

What we see around is not the only real model of the world but one of the numerous possible world models - moderated by our senses and cognition. Out of the numerous logically and factually possible worlds of perception as summed up by the biologist Richard Dawkins in his lecture $\left(2005^{2}\right)$ we perceive a fairly narrow range of reality, constrained predominantly by our human neurophysiology ${ }^{3}$. Like in economics, the theory of the second best concerns the

1 Part of the present paper was delivered as a plenary lecture at online Cognitive Linguistics conference organized by Wrockaw University on 1-3 December 2016 and is available at https://sites.google.com/site/coglingwroc2/plenary-lecture/barbara-lewandowska-tomaszczykplenary-lecture

2 Richard Dawkins Why the universe seems so strange. [Online]

Available from: https://www.ted.com/talks/richard_dawkins_on_our_queer_universe

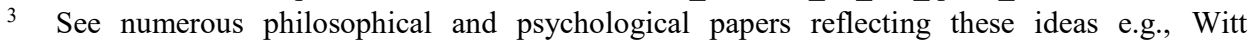
and D. R. Proffitt (2007). 
situation when one or more optimality conditions cannot be satisfied ${ }^{4}$, we have an analogical situation in the case of human perception. The focus of the paper is on the ways how and what extent the human frame of reference determines our understanding and communication. To paraphrase Wittgenstein, who said in his Tractatus Logico-Philosophicus (1921:5.6): Die Grenzen meiner Sprache bedeuten die Grenzen meiner Welt. 'The limits of my language are the limits of my mind' and then All I know is what I have words for I propose to discuss the question of the limits of my world that impose the limits on my language. More particularly, I want to argue that all communication is a matter of degree, and it presents what I first called meaning approximation in LewandowskaTomaszczyk (1999, 2012a), from which part of the present contribution originates. Crucial reasons for such a state of affairs, connected with the interpretation of the phenomena of sameness, equivalence, and similarity or resemblance will be discussed in the second part of the paper.

\section{Vagueness}

Meaning approximation is rooted in the presence of vagueness associated with two basic domains. The major distinction of all perceptual and - as a consequence - conceptual approximation - is between ontological vagueness on the one hand and epistemological (cognitive) vagueness on the other. Some things present - by their very character - an almost nature (to use the term proposed by the mathematician Sossinsky (1986), for which no exact definition exists such as in the case of some abstract and emotion concepts. They are instances of ontological vagueness.

Epistemological vagueness on the other hand involves what Sossinsky calls their more-or-less nature. They are those for which exact meanings do exist but for various reasons discussed further, the meanings are either inaccessible or volitionally disregarded.

Ontological vagueness involves then natural, existential absence of criterial properties of concept identification. The object cannot be satisfactorily defined because its boundaries are fluid and/or the content - non-cohesive. Epistemological (cognitive) vagueness on the other hand occurs in the situations in which there may exist necessary/sufficient meaning criteria for a linguistic sense definition but, due to various social, psychological (volitional, deontic), linguistic typological, or contextual reasons, they are not fully exploited in particular contexts.

4 The theory of the second best in economics concerns the situation when, as shown by the economists Richard Lipsey and Kelvin Lancaster (1956), if some optimality conditions cannot be satisfied, it is possible to constrain the system so that at least one variable must assume a value other than the first-best value. The model has also achieved some currency in social, political and legal theories. 


\subsection{Interpretive Multiplicity}

Connected with epistemological vagueness is the presence of language interpretive multiplicity. How is it conditioned? Meaning of any semiotic system is part of a general organization of mental structures with its exponents on a visual, aural, tactile, gustatory, or linguistic level. Semantic signs, by their very nature, are typically not fully specified, so to achieve fuller interactional understanding they have to be complemented by inferential structures - a speaker's/listener's abilities to complete a message with unexpressed thought(s) or image(s). The inferential meanings reached by induction or abduction lead to meaning extension in terms of familiar knowledge frames, the extension not always identical to the one originally meant by the speaker (see Coulson, 2001 for a more extensive discussion). Say, Mary repeats what she heard from her friend Ann I couldn't find my purse and there was this man running... and Mary, reporting the event to me, says Ann couldn't find her purse and then there was this THIEF running. The information whether the person running was or was not a thief was not originally specified, as the meanings of the signs used did not describe the event in fuller detail. This enabled an additional, unintended, unexpected or in some cases - wrong - inferential interpretation with the addressee, due to some strongly entrenched frames of stereotypic experiences (Fillmore, 1982) concerning a typical course of action under such circumstances, in other words, Idealized Cognitive Models (ICMs) of events (Lakoff, 1987).

One can thus conjecture that comprehension and interpretation of linguistic meanings are always related to this interpretive multiplicity in language, rooted in and originating from a limiting nature of human perceptual/conceptual experiences, particular properties of world languages as well as the nature of verbal interaction and its contextual conditioning.

\subsection{Effability}

The relation between thought and language has always been - for millennia - a subject of philosophical theorizing, particularly with reference to the phenomenon of effability. Some of our thinking tends to be more effable, i.e., possible to express in a language, while its large part, particularly image-verbal thoughts, visions, emotions or dreams remain more felt than expressed, more imagined than put in words. Jerrold Katz's Principle of Effability (1978) proposes that every thinkable thought in natural language can be encoded and expressed by a sense of some sentence in language, however it does not find satisfactory support in today's research (e.g. Sperber and Wilson, 1995).

Language typological parameters, which constrain the expression of some of thoughts, act as a constraining parameter too. Some ontological categories are verbally marked and can be expressed in a number of languages, while some others are absent or left non-verbalized in the system (as e.g., the category of grammatical gender or most of the nominal case system in English). 
Structural ambiguities typical of particular linguistic systems are also responsible for the absence of full interactional comprehension like, e.g. the word order ambiguities between the Agent and Patient in Polish with their grammatical homonymy between the Nominative and Accusative Neuter Nouns (ciele (Nom./Acc.) 'calf'). Other examples include logical - as opposed to pragmatic - ambiguities as to the order of the actions in the and-conjoined constructions (I had lunch and went shopping - but in a different order) or referential vagueness in utterances.

\subsection{Ability, permission and volition}

Apart from these typological linguistic constraints on communication and understanding, there are certain meanings the speaker can take the liberty of choosing in order to convey a message such as adopting a particular semantic perspective via different profiling and construal of a given scene or event (Langacker, 1987, 1991). Also the level of granularity is what matters here.

Degrees of linguistic expression of thought are also partly a matter of authorization (permission) to inform about a particular state of affairs, i.e. to give details concerning particular events. Moreover, further constraints in discourse context involve the question of individual intentions. The speaker may not wish to share all thoughts, feelings, etc. linguistically (or otherwise) with the interlocutor (volition). Last but not least, the phenomenon of approximation is related to the speaker's linguistic repertoire (linguistic competence). First of all, speakers have, as a rule, varying language repertories which overlap to different degrees and some may be a more and some others - less, faithful portrayal of the speakers' thoughts which they are prepared to share with others. Thus, these sources of meaning approximation lie at the interplay of ability, deontic conditions and volition.

\section{Interactional communication}

In interactional discourse we observe the lack of symmetry in the scope and range of conceptual-semantic spaces across discourse participants. This condition rests within the sphere of the speakers' knowledge of the world and the breadth of their respective concepts. Furthermore, as argued above, verbal communication is not always overtly explicit. There are contexts in which conversational contributions strike a, more or less, similar semantic level, the ideal level in terms of Gricean conversational maxims (Grice, 1975). Some others - do not.

One very interesting, related, aspect of communication is the phenomenon of politeness, particularly with reference to so-called minimizing strategies, which are basically face-saving ways to communicate meanings (first related to a discussion of distancing and language functions in Malinowski 1936, then 
developed in Gumperz 1982 in terms of contextualization cues). Some of these strategies have to do with approximative meanings via their indirectness. Would you be so kind and try to put your luggage back on shelf so that I could get in? does not represent a particularization communicative strategy per se but rather an impoliteness minimizing strategy, which is fairly approximative when one considers the semantic content of the sentence.

Apart from this basic conditioning of communicative approximation, there are also other, psychological and psycholinguistic factors, like memory lapses, interruptions, and the like, which are partly responsible for the processes of approximation.

To reassume then, it can be argued that for ontological, cognitive, volitional or deontic reasons, together with typological linguistic conditions, language speakers do not or cannot furnish the linguistic forms they use with the content of absolute identity with their conceptual intentions but rather they resort to the 'second, third, or nth best' options in communication contexts - both in monolingual discourses and even more so in intercultural encounters and translation.

\subsection{Resemblance}

And yet, we $d o$ communicate - we find evidence for this in common enterprises leading to jointly-planned outcomes, we can predict some events, we collaboratively develop ideas and put them in practice. The same forms used appear to bear some degree of resemblance to the originally intended thought (deliberate lying must be excluded here), although identity - that is a symmetrical one-to-one relation between things - is not what is observed. Rather, as argued for in the present paper, linguistic expression exhibits a stronger or weaker, typically one-way, conceptual resemblance to the thoughts intended and to identical forms used in interaction. Although not identical, such corresponding senses and meanings tend to foreground some most salient similar meaning properties, typically associated with the forms as used either by interactants in one language or across languages. Similarity is this context involves both the foregrounding of resemblance across various dimensions but, at the same time, also emphasizes differences, responsible for the processes of what I label meaning re-conceptualization (Lewandowska-Tomaszczyk, 2010).

\subsection{Re-conceptualization of meaning 5}

Communicative activities involve a re-conceptualization of an original message as received by the Addressee in terms of their modification of both conceptual-

5 In some papers dealing with this matter the non-hyphenated spelling reconceptualization is used. 
semantic content the message conveys and the way the content is constructed in a communication act. Each time when such a unit is repeated and used in new contexts, by different speakers, the meaning enters a new re-conceptualization cycle to form a hybrid, blended entity, which combines elements of the message sent by the Speaker and those residing in the Addressee's cognitive models, repertoire and background knowledge frames.

\section{Cross-linguistic displacement of senses}

In cross-linguistic comparisons what is conventionally observed are weakly commensurable (Lakoff, 1987) categorical hierarchies in language and, rooted in them, a dynamic displacement of senses (cf. Lewandowska-Tomaszczyk, 1987).

The cross-linguistic relationship is typically asymmetrical, not calibrated (see Lakoff, 1987). Lexical forms can be more semantically branched in one language than in another, with the polysemic, categorial or subordinate (hyponymic) clusters of concepts in the former that bear degrees of similarity (on a number of varying criteria) to those diverse forms in the latter, which can be more or less numerous in their branching. The form compromise in English with its extended cluster of polysemic senses involves the meaning of concessions in settling a dispute in some contexts, the sense of weakening and worsening in another, or else the sense of exposing a person to disrepute in still another one. Those English senses correspond to a displaced cluster of a more varied, inter-categorially linked, forms and concepts in Polish as observed in (1):

(1)

(i) They developed a compromise 'Doszli do kompromisu'/ They are ready to compromise on these points 'Są skłonni załatwić te punkty w sposób kompromisowy'

(ii) That requirement compromises the security conditions. 'To żądanie osłabia bezpieczeństwo'

(iii) They compromised themselves. 'Skompromitowali się.'

The intra-semantic conceptual resemblance in English is much stronger in this case than that in the corresponding Polish set of meanings, which do not even form a cohesive semantic cluster as judged by an average Polish user. They are rather considered members of distinct semantic categories KOMPROMIS, OSŁABIENIE/POGORSZENIE, KOMPROMITACJA, which are not identified as showing a particular resemblance relation with one another. 


\section{Translational equivalence}

Taking the conclusions presented above as premises for further arguments, a question can be asked with regard to the position of the concept of equivalence in translation. Equivalence in translation is understood in the present study in a broad sense as typically partial meaning resemblance between concepts, always mediated by re-conceptualization processes. Moreover, all re-conceptualization processes are regarded to be conditioned by a conceptualisation type represented by a particular linguistic unit, a degree of its prototypicality and entrenchement, type of construal and a range of naturalness in a particular context. Langacker (1987: 52) proposes that language is a set of structures graded with reference to their prototypicality and entrenchment. Ernst Gutt (1991) uses in this context the concept of "interpretive resemblance, the sharing of thoughts between the intended interpretations, which in fact forms a continuum, between full and zero resemblance". It is the theory of Relevance (Sperber and Wilson, 1986) first of all, which involves an interpretive use of language relying on resemblance in semantic representation or logical form. Gutt modified the claim to cover cases of inter-lingual communication, viz. translation, and proposed that translation should be considered interlingual interpretive use based on interpretive resemblance, i.e. a degree of similarity between various interpretations of a given form (consult Lewandowska-Tomaszczyk, 2015). In the terms proposed in the present paper, the parameters which function as the basis of a judgment concerning the degree(s) of resemblance between linguistic forms and their reconceptualization measure include first of all the judgment as to a distance between the meaning used to that of a category prototype, then the degree of its entrenchment in a particular linguistic system and in the linguistic system of their user(s), type of the meaning construal (with reference to the structure of objects and events, together with their semanticized form) and the degree of naturalness (Lewandowska-Tomaszczyk et al., 2001), based on the frequency of the use of these meanings and their forms in a particular context.

\section{Resemblance}

A typology of resemblance, similarity, or equivalence, i.e., forms of equal valence, although neither fully symmetric, nor reflexive or transitive as the concept of identity in logic and mathematics, covers a variety of cases, from oneto-one prototype equivalence in the perceptual, functional, axiological, etc. terms, via equivalence of logical truth, ideology, metaphor, polysemy constituents (see Lewandowska-Tomaszczyk, 2007), to pragmatic functional equivalence, even more diverse and varied.

Resemblance is not a context-free idea but rather a dynamic notion. While a rose resembles a peony on the one hand and a pine tree is similar to a fir-tree on the other, there is much smaller similarity between a rose and a fir tree, even 
though they are similar on a general level of PLANTNESS and ANIMATENESS (see Gärdenfors, 2004: 4, for the comparison).

In this context three major classes of equivalence can be identified (Lewandowska-Tomaszczyk, 2013a, 2013b): generalized, with equivalence captured on higher categorization levels, parallel, more closely aligned, typical for domain-specific texts, and particularized (particulate) equivalence, engaging a fine-grained, more explanatory specification of word meanings, either by going deeper into semantic precision or else covering comparative semantic levels of a wider range, reaching over to inter-categorial extensions.

Particularization and Particulate Communication can take different paths. Depth particularization provides a more detailed description of the meaning, frequently in definitional terms, e.g., the form of a 'cohort studies', that is following single age groups through successive periods (BNC). Width particularization involves extending the meaning, typically by creating new, inter-categorial links which frequently exploit figurative, most often metaphorical, resemblance as in This links itself to the three previous parts because it displays a process which metaphorically or symbolically represents change (BNC), while Gestalt particularization approaches functional equivalence and involves substituting an original portrayal of an event with a different one, nevertheless maintaining some salient aspects of resemblance, also in terms of implicational content e.g. A: Debbie knew how to defend herself, I saw to that, but a kidnapping's something else. B: What exactly do you mean by 'defend herself'? A: In America the police in major cities run courses that teach women to defend themselves, particularly against rape (BNC).

Equivalence can thus be limited to a 'coarse-grained picture' of linguistic meaning as in generalized equivalence, while in order to achieve a 'fine-grained picture' what is needed is access to the networks of both linguistic, encyclopaedic as well as interactional (on-line discourse) meanings, all aspects of which are possible reference levels for translational or monolingual communicative correspondences as when one employs in utterances interchangeably different levels of knowledge frames as in switch on the light [profiling the resultant stage of the activity light] - switch on the lamp [profiling a device of giving light with a bulb, holder and shade] - switch on the bulb [profile of a direct light emitter i.e., bulb].

Approximating strategies are particularly visible in casual spontaneous conversation, in which more is assumed than said, more is contextualized than expressed, or else, when a lot is said, it is usually at a fairly superficial level of communication. Particulate communication (particularization), quite often called forth in conversation, typically involves general definitions in informal contexts, sometimes repetitions or paraphrases, as observed in English conversational corpora ( 2 and 3 , italicized): 
(2)

at about half past seven tonight, after a tiring day at school, you know it's always tiring at Christmas time, making decorations and all this sort of nonsense and things you know

$492 \mathrm{~A}$

$\mathrm{m}$

493 No C, Clara Bow

494 I haven't even heard of her

495 On the good ship lollipop oh that was Shirley Temple

$\mathrm{m}$

496 The other one was a bit silly really cos it says what is not a shag ? $\mathrm{f}$

497 What is not a shag?

$\mathrm{m}$

498 Yeah, but it, erm, er something dance in the sixties, a medieval something or other

and something else

In written texts and translation one can also use glosses and footnotes to particularize and deepen the meaning layers. And yet, it should be remembered that glosses, footnotes and paraphrases, do not bring about identical meanings. Each new wordform, notwithstanding the fact whether it is of a particularized form, or else a lexicalized same-language synonym in one language or a oneword equivalent across languages, which satisfies the conditions of parallel aligned equivalence, possesses its own systems of meaning layers - conceptual, connotative, affective, thematic, etc., so meaning equivalence provided by particularization and alignment, cannot by definition provide the same meaning on the plane of content and construal. Compare (4):

37 Honda have just recently produced a motorbike that erm is microcomputer controlled.

38 There's also things like head up displays for cars.

39 Sorry, what do you mean 'head up' displays?

40 Well this is the situation where you would ideally you don't want to have to look down at a speedometer.

Question (39) in (4) is a request for clarification of the phrase, while (40) makes reference to situations in which such devices are used, so it does not provide what can be considered a definition in a strict sense of the term. Furthermore, each form used in the answer activated a range of meanings different from those in the item head up in (39). 
Actually then, in no one of the three types of equivalence (generalized, aligned, particulate), are the forms considered equivalent in different languages, fully commensurable. It is rather a whole array of forms and senses with relevant concepts in either the linguistic variety as used by the speaker or in a given source language that corresponds to a lexical form or a cluster of forms in the other variety or language as used by the speaker.

\subsection{Tolerance spaces and the tolerance threshold}

In models of resemblance, it is hypothesized (Gärdenfors, 2004) that there exists a certain (determinate) tolerance space between meanings meant by the Speaker/Writer and the Addressee or Source Language (SL) and Target Language (TL) users, with a whole range of possible reconceptualizations of the source materials. The tolerance space is bounded by a certain, contextually defined, tolerance threshold that would curb the proliferation of the senses beyond a certain resemblance category - in order to counteract misunderstanding and a communicative failure. Peter Gärdenfors (2004) might have been inspired by the ideas of Roger Davidge Doherty and his colleagues (2003) and their investigation on texture deformation processes to see analogies with the linguistic phenomena. Gärdenfors treats similarities in terms of physical geometry as captured by the basic notions of betweeness and equidistance on a dynamic cline.

The questions arise as to the identification of the constraining factors on the semantic similarity and the tolerance measures and the tolerance threshold for semantic differences even if the language used by discourse participants is the same. In the light of the previous discussion of resemblance its tolerance threshold must be considered dynamic and context-sensitive, investigated with reference to a possible range of structures and meanings in the exchange and which fall within the lower and upper bounds of tolerance spaces, as Gärdenfors proposes. In an exchange, say, in which the word son is substituted by the more general boy (I have one boy) the approximate meaning associated with boy falls obviously within the (upper bound) tolerance space while the word man would clearly cross the threshold in this particular context and fall outside it. On the same note, while, say Peter, might be considered within the space in this context (This is Peter/my son), it would fall outside the (lower) bound in in the sentence signifying possession (I have a son/?Peter ${ }^{6}$ ). So, meanings can be viewed as Gärdenfors proposes points of a tolerance space, while similar meanings (synonyms, equivalents, parphrases) are "within tolerance if they resemble each other in a certain specified sense". It is also clear that the testing of the semantic

6 The sentence I have PETER with an emphasis on the item PETER, on the other hand will be interpretable in contrastive terms, e.g., as a reaction to the statement as in: A Your wife left you B (but) I have PETER 
tolerance threshold takes place in terms of syntactic constraints in actual language use.

The contexts in which particular meaning forms would cross the threshold and fall outside the space are significant. They are typically signaled verbally, e.g., by an interactional rejection (Rubbish!), misunderstanding (Did I get it right?) or lack of comprehension (I don't understand it), possibly accompanied by attempts of concept clarification.

An interesting aspect of discourse approximating strategies to narrow the gap in meaning is presented in neologisms and novel uses of language phraseology, e.g. in peacetime person in (5) from a corpus of English conversations (Svartvik 1990):

A: that would suggest that other countries must keep such people on tap rather wastefully for decades, what about all the people who turn out in wartime to be fir instance brilliant for cyphers [...]

B: $\quad[\ldots]$ you don't need them during peacetime

$[\ldots]$

A: I must say I don't think I'd be much use in a war, I feel I think I'm essentially a peacetime person

Jokes and humour are classic examples of semantic approximation as in this jokingly indirect request drawn from SPOKES BNC corpus (6):

515 I remembered the noise I remembered the noise as we went past the pub, so I went $\mathrm{m}$ back to the pub and sure enough there were fifty Sorry thirty burly men.

It was er er er rugby union obviously. There were at least thirty big men. $\mathrm{m}$ I said Excuse me lads, just before you start playing $\mathrm{m}$ can you give us a hand? 
and it's too light at the

back.

Can you Oh, they thought

this was great.

$\mathrm{m}$

However, for jokes to be interpreted in accord with the speaker and their intentions, the addressee needs to activate the whole underlying system of knowledge frames which are to undergo a semantic leap (Coulson, 2000) towards a semantic effect as planned by the speaker, in the case of (6) - the frame of a van and its functions.

Of special significance are also the novel uses and/or contexts as presented in children's language (full size horsy in 7), which can involve, as in this case, an approximation to a conventional phrase-formation mechanisms:

504 Nana there's that shop with that horsy in.

505 Oh on the Kettering Road?

$506 \mathrm{Mm}$.

507 Used to have a beautiful, almost full size wasn't it?

508 What do you mean full size?

509 Horses come in different sizes.

510 Well it wasn't a small model.

511 But you get small ponies, I mean it could be a life size model of a horse that big.

Some other exchanges (8) exemplify mostly the attitudinal and emotive meanings, approximate by their very nature, as in the case of a narrative in which the phrase (agricultural) characters is used with reference to farmers or villagers and the form chinz for Indian printed cotton cloth and some very informal expressions (bloody boil):

straight into the public side of the bar; the nearest corner bar; and there were a certain number of characters who I think were waiting to sell some sheep or some cattle or something, mostly agricultural characters and obviously in the way, little chinz the little little you know transparent curtains were fluffing, they'd been watching the whole thing from their little corner and there was this sort of the bloody boil 
To put it briefly, we can conclude by borrowing Gärdenfors's definition (2004: 165) of communication modelling as a certain tolerance space maps.

On the other hand, what cannot be disregarded in the discussion of meaning approximation is the value and significance of Gumperz's 'contextualization cues' (1982). Gumperz (1982: 133) proposes that "a contextualization cue is any feature of linguistic form that contributes to the signaling of contextual presuppositions" and they involve both linguistic signals such as prosody and intonation but also connotative, stylistic, etc., and others from higher levels of language representation. Interactants accommodate in discourse and that is how new uses and generalized approximation come into the system and can be viewed as semantic shortcuts in language communication.

The substitution of meanings both in one language or across languages is thus based on the (partial) broad semantic similarity. The similarity is observed on the perceptual/functional/axiological etc., levels, as well as (total or partial) form similarity, e.g., when the observer identifies similarities across phonetically or prosodically (dis)pleasing sounds or intonation across different languages and is impressed with the similarity of the approximate semantic effects received. The effects on the Addressee of the forms which display some types of similarity are reminiscent of Austin's utterance perlocutionary effects (1962), affecting the listener. For example, the English form teeny weeny indicating a small size, signalled by sound symbolic vowel clustering, may be considered equivalent to the effects generated by the diminutive suffix in the Polish form malusieńki. The phrase sharp scratch - equivalent to Pol. ostry zgrzyt can be taken to employ the same type of fricative consonants in both languages to achieve a desired semantic-acoustic effect of the scratching sound, approximating the original to some extent ${ }^{7}$.

Other types of examples can be given to present resemblance by the substitution of some emotion terms for others in some discourses. Such a substitution exemplifies admissible approximations falling within a particular tolerance space: fear is intersubstitutable with anxiety and Polish strach with lęk and niepokój from the same conceptual cluster of emotion terms (see equivalence patterns in (11)), while to substitute fear for say contentment might signal crossing the allowable boundaries of the space - at least in prototypical contexts.

\subsection{Methods of resemblance identification}

In general terms, a methodology of resemblance identification involves qualitative and quantitative methods. In quantitative terms, similarity, as

7 It would require further experimentation to investigate the degree of the similarity between the two phrases in terms of a comparison of corresponding perlocutionary (sound symbolic) perception effects on English and Polish audiences respectively. 
proposed in the present work, is calculated on the basis of a frequency of cooccurrence of a unit (word, phrase, sentence) with other units in the same contexts. In order to calculate meaning differences the relevant linguistic units need to be juxtaposed in varying contexts and their frequencies calculated as e.g., in collocations with a continually larger and larger contextual span. Other frequency-based counts, besides contextual co-occurrences of lexis (collocations), lexical density, type/token ratio and word keyness can also be considered.

Qualitative research methods focus on Extralinguistic Aspects such as cultural dimensions, background knowledge frames or the speaker's personal (idiosyncratic) preferences on the one hand and Intralinguistic Aspects involving language typological criteria, stylistic parameters as well as construal parameters in a board sense such as profiling, granularity etc. on the other.

Both monolingual communicative as well as translational points of reference in establishing resemblance of meaning across texts function as factual tertia comparationis in this process. For a communicative success to be interactionally achieved, there must exist some constraints on the perceived resemblance between concepts as used by the speaker and those interpreted by the addressee. The constrains are put on a scale of reconceptualization patterns which function as markers of a particular resemblance identity space, bounded by upper and lower tolerance thresholds with a gradable range of conventional interpretations.

Thus the most typical reference point to establish resemblance is the (perceived) similarity to a prototype of different nature as exemplified in one language synonymy and in translational correspondences (see Resemblance Matrix below).

\section{RESEMBLANCE MATRIX}

I. Reference to a prototype [distinct culture-bound prototypes]

Broad semantic criteria

(i) perceptual [visual, acoustic, etc.] e.g., houses of different styles and design, prototypically possess a roof and an entrance (e.g. Eskimo igloo 'dome-shaped Eskimo hut, made of blocks of hard snow', 'house, 'dwelling of any dome-shaped construction' (Greenlandic igdlo "house"); perceptual resemblance - basis for metaphoricity pony > pony tail [possibly crossing inter-categorial boundaries]

(ii) reference to peripheral members, particularly in cross-linguistc concepts (e.g. Eng. robin in the English category of BIRDS and a corresponding wróbel 'sparrow' in Polish, with robin considered a more peripheral member)

(iii) radial categories [polysemy constituents], involving in-group category members and inter-categorial links (reference to polysemic clusters in Lakoff's sense, 1987), possibly crossing the boundaries of one conceptual category. 
(iv) functional equivalence (e.g., Eng. home - Swahili nyumbani 'hegave thehouse' as 'peaceinmy home'; Pol. województwo 'voivodshop' - Eng. 'county, province'; in the Lord's Prayer Eng our daily bread - Eskimo our daily fish Nida 1992; intralinguistic resemblance Eng. symptom sign)

(v) emotional [intra and interlinguistic resemblance: Pol. lęk-strach/ Eng. anxiety/fear]

(vi) axiological [patriotism contrasted with or perceived as nationalism]

(vii) conceptual coarseness / granularity (e.g., Eng. in-laws - Po. 'family from husband's side', non-lexicalized in some languages; Pol. collective nouns e.g., kwiecie (flowers perceived as mass) - Eng. flowers vs. Pol. listowie - Eng. foliage.

II. phonetic resemblance - typically sound symbolic - similar acoustic-meaning effects. (e.g., neologisms in translation) e.g.:

Lewis Caroll's Jabberwocky

Eng. the slithy toves -

translated into a number of versions into Polish such as, e.g.:

Pol. 1. 'jaszmije smukwijne’ (by Maciej Slomczyński),

Pol. 2. 'ślimonne prztowie' (by Stanisław Barańczak),

Pol. 3. 'szlisgich hopuch świr' (by Janusz Korwin-Mikke)

Each of the above examples of Jabberwocky translations into Polish introduces also similar semantic effects by exploiting morphological/sound symbolic semantic similarities across the two languages, e.g. slithy > smukwijne/ślimonne/szlisgich

III. identical truth conditions, but different connotative meanings, e.g., Eng. honeysuckle (Latin Lonicera), metaphorically connoting sweetness and tenderness - Pol. botanical equivalent wiciokrzew przewierceń (Latin Lonicera periclymenum), both denote plants that grow along the ground, along another plant, or up a wall. The Polish form activates the connotations contrasting with those in English; it is primarily associated with creeping (Eng. creeper), penetrating, insinuating itself, thus involves negative contexts, opposite to the connotations associated with Eng. honeysuckle (example quoted from Jerzy Jarniewicz, 1992).

IV. ideology (Eng. my home is your home used as equivalent of Pol. gość w dom, Bóg w dom lit. 'guest (at) home, God (at) home')

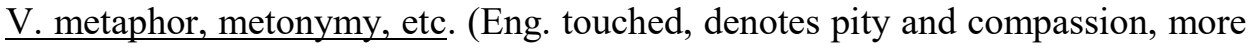
foregrounded than in one of its Polish 'touch' equivalents such as dotknięty lit. 'touched', synonymous to Pol. urażony 'hurt, angry, sad') 
VI. associative aspects, e.g., those based on intertextuality; (e.g. the title of a novel by a Polish science-fiction writer Stanisław Lem Głos Pana lit. 'Lord's/Master's Voice', associated with God and religious context, or linked to the meaning of a master and slave. Eng. translation His Master's Voice, also activates the master image, but additionaly connotes a trademark in the British music business 1890 with this dog listening to a cylinder phonograph (Lewandowska-Tomaszczyk, 2010).

VII. recontextualization, i.e., a modification in accordance with a new context conditioning (e.g., a running commentary on a winning football match of a Polish team: Poland win - recontextualized as we win by a Polish translator).

VIII. perspective change e.g., via changing of the focus in terms of syntactic shifts (e.g., the active-passive voice contrasts I received/got those flower - I was given those flowers - They gave me those flowers - Those flowers were given to $\mathrm{me}$ - Those flowers were received by me).

IX. pragmatic equivalence of discourse functions as e.g., in the adjacency pairs Eng. Thank you - You're welcome Pol. Dziękuję - Proszę Pol. 'Thank you' lit. 'Please'

In all those categories a change of construal and a reconceptualization process are at work in interaction. The translated interpretations typically exhibit varying degrees of distance from the original thought and semantic content.

\section{Cluster equivalence as a norm prototype - Cultural Models}

The observations made with reference to intralinguistic communicative equivalence - synonymy, polysemy, paraphrase - and cross-linguistic equivalence, including translational correspondences between one language and another, unambiguously lead to positing a thesis concerning the presence of intra- and inter-linguistic cluster equivalence, which would replace conventional word-for-word or phrase-for-phrase substitution proposals. A systematic study of parallel corpus data, in the present case - the PARALELA PELCRA corpus at Łódź University - analysed with the corpus tools developed by Piotr Pęzik (2014) at Lodz University, provides ample evidence for a displacement of senses between English and Polish and generates large numbers of series of Polish-toEnglish and English-to-Polish cluster equivalence patterns. The Polish form zgoda can be presented as one such example. The form corresponds to a number of English equivalents in a cluster, which denotes understanding and agreement such as consent, approval, acceptance, assent, agreement unanimity, reconciliation, etc., primarily in legal and administrative contexts, our yes, go ahead, this cannot be refused in political negotiation discourse, as well as 
largely informal that's right, that's all right, that's all settled, very well, well then, etc. in informal spoken discourse. Each of the cluster members it turn, corresponds to an equally rich cluster of Polish equivalents, combined around the category of agreement, but also extending over to other conceptual categories, which presents instances of English-to-Polish displacement of senses.

One can also make an attempt to infer more complex Cultural Models as well as the models referring to the construal of meanings and their tolerance spaces from parallel corpus data and cluster equivalence patterns, using quantitative measures and qualitative analysis of keywords and collocational profiles (Lewandowska-Tomaszczyk, 2012; Lewandowska-Tomaszczyk \& Wilson, 2015). Cultural models capture distinct social conditioning of concepts, and can denote everyday habits and activities or more abstract thinking and reference. Examples can be given based on word and keyword frequencies as e.g., the frequencies of use presented in the decreasing order with respect to the object of drinking in English corpora: water, tea, beer, wine, champagne, and whisky, generated on the basis of their frequencies in English corpus samplers $(20 \mathrm{mln}$, Microconcord and Longman corpora), vis-à-vis the decreasing frequencies of the collocates with the Polish verb pić 'drink' and its derivatives. The forms alkohol 'alcohol', wódka 'vodka', piwo 'beer', wino 'wine', and woda 'water' are evidenced in the Polish language data, specifically in PELCRA samplers of a comparable number of units to those of the Microconcord and Longman corpora (Lewandowska-Tomaszczyk, 2012). Below drink (9) and pić (10) collocates are presented as sources of cross-linguistic and cross-cultural comparison. They are generated from the British National Corpora and National Corpus of Polish respectively, using the HASK collocating tool (http://pelcra.clarinpl.eu/hask_pl/, Pęzik, 2014). The large data confirm the collocation patterns identified in the smaller corpora with tea, coffee, water, wine at the top of the list with food occupying the first position in English and alcohol, beer, coffee and tea - dominating in the Polish collocations (columns A in (9) and (10) indicate frequencies of particular collocations). When juxtaposed to English (9) the Polish list (10) presents also a less varied drink collocate pattern, referring to types of drink than that observed for English. 
(9) drink Nominal Collocates ${ }^{8}$

\begin{tabular}{|c|c|c|c|c|}
\hline \# & Collocate & POS & A & TTEST \\
\hline 1 & food & N\% & 224.0 & 14.36 \\
\hline 2 & tea & $\mathrm{N} \%$ & 172.0 & 12.84 \\
\hline 3 & coffee & $\mathrm{N} \%$ & 162.0 & 12.50 \\
\hline 4 & water & N\% & 136.0 & 10.29 \\
\hline 5 & wine & N\% & 103.0 & 9.84 \\
\hline 6 & beer & N\% & 63.0 & 7.73 \\
\hline 7 & cup & $\mathrm{N} \%$ & 68.0 & 7.55 \\
\hline 8 & alcohol & $\mathrm{N} \%$ & 58.0 & 7.44 \\
\hline 9 & lot & $\mathrm{N} \%$ & 71.0 & 7.18 \\
\hline 10 & pint & $\mathrm{N} \%$ & 50.0 & 6.96 \\
\hline 11 & milk & $\mathrm{N} \%$ & 50.0 & 6.77 \\
\hline 12 & whisky & $\mathrm{N} \%$ & 39.0 & 6.11 \\
\hline 13 & glass & $\mathrm{N} \%$ & 42.0 & 5.69 \\
\hline 14 & champagne & $\mathrm{N} \%$ & 34.0 & 5.69 \\
\hline 15 & bottle & $\mathrm{N} \%$ & 27.0 & 4.71 \\
\hline 16 & toast & $\mathrm{N} \%$ & 20.0 & 4.37 \\
\hline 17 & drink & $\mathrm{N} \%$ & 24.0 & 4.30 \\
\hline 18 & brandy & $\mathrm{N} \%$ & 16.0 & 3.90 \\
\hline 19 & sherry & $\mathrm{N} \%$ & 15.0 & 3.80 \\
\hline 20 & juice & $\mathrm{N} \%$ & 14.0 & 3.52 \\
\hline 21 & ale & $\mathrm{N} \%$ & 13.0 & 3.51 \\
\hline 22 & drug & $\mathrm{N} \%$ & 19.0 & 3.34 \\
\hline 23 & rum & $\mathrm{N} \%$ & 11.0 & 3.26 \\
\hline 24 & gin & $\mathrm{N} \%$ & 10.0 & 3.08 \\
\hline 25 & guinness & $\mathrm{N} \%$ & 10.0 & 2.98 \\
\hline 26 & whiskey & $\mathrm{N} \%$ & 9.0 & 2.97 \\
\hline 27 & smoke & $\mathrm{N} \%$ & 11.0 & 2.95 \\
\hline 28 & stuff & N\% & 13.0 & 2.79 \\
\hline 29 & soup & N\% & 9.0 & 2.79 \\
\hline 30 & vodka & N\% & 8.0 & 2.77 \\
\hline 31 & orange & N\% & 9.0 & 2.76 \\
\hline 32 & litre & $\mathrm{N} \%$ & 8.0 & 2.68 \\
\hline 33 & lemonade & $\mathrm{N} \%$ & 7.0 & 2.61 \\
\hline
\end{tabular}

8 The first column in the collocate tables indicates the frequency of occurrence ranking, the second (Collocate) identifies a particular collocate. The column POS identifies the collocate part of speech, column A presents the frequency of occurrence of particular collocations in BNC and NKJP respectively (National Corpus of Polish), and the last column TTEST shows the significance level of the frequencies. In Polish collocate tables, English equivalents are provided. 
(10) pić Nominal Collocates

$\begin{array}{llllll}\# & \text { Collocate } & \text { POS } & \text { A } & \text { TTEST } & \\ 1 & \text { alkohol } & \text { noun } & 1249.0 & 35.06 & \text { 'alcohol' } \\ 2 & \text { piwo } & \text { noun } & 913.0 & 30.01 & \text { 'beer' } \\ 3 & \text { kawa } & \text { noun } & 775.0 & 27.66 & \text { 'coffee' } \\ 4 & \text { herbata } & \text { noun } & 700.0 & 26.30 & \text { 'tea' } \\ 5 & \text { woda } & \text { noun } & 737.0 & 26.01 & \text { 'water' } \\ 6 & \text { wino } & \text { noun } & 650.0 & 25.23 & \text { 'wine' } \\ 7 & \text { wódka } & \text { noun } & 634.0 & 25.04 & \text { 'vodka' } \\ 8 & \text { mleko } & \text { noun } & 273.0 & 16.27 & \text { 'milk' } \\ 9 & \text { sok } & \text { noun } & 154.0 & 12.30 & \text { 'juice' } \\ 10 & \text { raz } & \text { noun } & 363.0 & 12.17 & \text { 'once' } \\ 11 & \text { wszyscy } & \text { noun } & 191.0 & 11.52 & \text { 'all' } \\ 12 & \text { co } & \text { noun } & 617.0 & 11.25 & \text { 'what' } \\ 13 & \text { szampan } & \text { noun } & 120.0 & 10.87 & \text { 'champagne' } \\ 14 & \text { napój } & \text { noun } & 115.0 & 10.50 & \text { 'soft drink' } \\ 15 & \text { umór } & \text { noun } & 96.0 & 9.79 & \text { 'get dead drunk' } \\ 16 & \text { krew } & \text { noun } & 113.0 & 9.48 & \text { 'blood' } \\ 17 & \text { butelka } & \text { noun } & 98.0 & 9.43 & \text { 'bottle' } \\ 18 & \text { jedli } & \text { noun } & 87.0 & 9.28 & \text { '(they) ate' } \\ 19 & \text { ojciec } & \text { noun } & 136.0 & 8.78 & \text { 'father' } \\ 20 & \text { zdrowie } & \text { noun } & 120.0 & 8.73 & \text { 'health' } \\ 21 & \text { szklanka } & \text { noun } & 78.0 & 8.54 & \text { 'glass' } \\ 22 & \text { ogół } & \text { noun } & 114.0 & 8.40 & \text { 'all' } \\ 23 & \text { ludzie } & \text { noun } & 213.0 & 8.30 & \text { 'people' } \\ 24 & \text { mężczyzna } & \text { noun } & 119.0 & 8.14 & \text { 'male' } \\ 25 & \text { whisky } & \text { noun } & 65.0 & 7.99 & \text { 'whisky' } \\ 26 & \text { kieliszek } & \text { noun } & 66.0 & 7.87 & \text { '(alcohol) glass' } \\ 27 & \text { herbatka } & \text { noun } & 60.0 & 7.68 & \text { 'tea (diminutive)' } \\ 28 & \text { kto } & \text { noun } & 170.0 & 7.62 & \text { 'who' } \\ 29 & \text { papieros } & \text { noun } & 68.0 & 7.56 & \text { 'cigarette' } \\ 30 & \text { drink } & \text { noun } & 58.0 & 7.52 & \text { 'a drink' } \\ 31 & \text { ilość } & \text { noun } & 77.0 & 7.43 & \text { 'amount' } \\ 32 & \text { polak } & \text { noun } & 54.0 & 7.34 & \text { 'Pole' } \\ 33 & \text { osoba } & \text { noun } & 218.0 & 7.12 & \text { 'person' } \\ & & & & & \end{array}$

The cross-linguistic collocation data, enriched by the qualitative discourse analyses of the materials, can help infer distinct Cultural Models in such cases, typical of particular language users' communities. They also epitomize language-specific approximation of meaning (for the verbs of drinking and their collocates in this case) as used in Polish and English discourses. 
Another dimension to exemplify cross-linguistic indeterminacy and ways to manage it in translation involves cultural models of emotions. As can be observed with respect to emotion models, e.g. FEAR terms in (LewandowskaTomaszczyk \& Wilson, 2013), a cluster of fear-related concepts in the verbal object position, generated from the corpus materials, indicate language/culturespecific fear causes and stimuli, both more universal e.g., death, crime - as well as also more restricted such as Nazi, or else individual and emergent like dogs. The latter categories are more varied and involve culture-specific Emotion Event scenarios (Lewandowska-Tomaszczyk \& Wilson, 2013). In numerous other cases typically presuppositional or implicational senses such as cowardice, are generated from extended distributional contexts. The causes, stimuli and other circumstantial properties of a concept in one language (SL, Polish in (11)) are often used as an extended cluster of translational equivalents in another language (English in (11)). What is also evident in (11) is the extension of the tolerance measures from a prototypical, more universal space via more extended, culturebound equivalence to individual and circumstantial conditioning of events.

Pol. STRACH-to-Eng. FEAR extended cluster

(i) Prototypical tolerance:

- Trivial tolerance: Pol. strach - Eng. fear

(ii) CLUSTER tolerance:

- Pol. strach - Eng. [arousal] anxiety, terror, horror

- Pol. strach - Eng. [presuppositional/implicational] cowardice

(iii)CAUSAL tolerance:

- [stereotypical - more universal] Pol. strach - Eng. death, crime

- [social] Pol. strach - Eng. Nazi, God

- [individual] Pol. strach - Eng. dogs [emergent]

Quantitative distributional data involving the frequencies of collocates are also revealing in respect of other complex emotion clusters. Love in English and mitość in Polish indicate a preferred companionate, family and religious profile for mitość (see 12) and a more individualistic one for English love (see 13) (Lewandowska-Tomaszczyk \& Wilson, 2015) in the sense of Hofstede's cultural dimensions (2001). 
(12) Pol. miłość 'love'

Nominal Collocates

$\begin{array}{llllll} & \text { Collocate } & \text { A } & \text { TTEST } & \text { MI3 } & \text { English equivalents } \\ \mathbf{1} & \text { bliźni } & 425.0 & 20.35 & 23.74 & \text { 'fellow human being' } \\ \mathbf{2} & \text { Bóg } & 529.0 & 13.48 & 19.36 & \text { 'God' } \\ \mathbf{3} & \text { ojczyzna } & 157.0 & 9.58 & 16.68 & \text { 'fatherland' } \\ \mathbf{4} & \text { polak } & 17.0 & 4.04 & 13.96 & \text { 'Pole, Polish' } \\ \mathbf{5} & \text { nieprzyjaciel } & 20.0 & 3.11 & 10.36 & \text { 'enemy' } \\ \mathbf{6} & \text { bliźnia } & 10.0 & 2.37 & 8.65 & \text { 'fellow human being' } \\ \mathbf{7} & \text { stwórca } & 12.0 & 2.00 & 8.41 & \text { 'creator' } \\ \mathbf{8} & \text { niejedno } & 12.0 & 1.82 & 8.24 & \text { 'not one, many' } \\ \mathbf{9} & \text { wierna } & 26.0 & 1.59 & 9.94 & \text { 'faithful' } \\ \mathbf{1 0} & \text { małżonkowie } & 15.0 & 0.48 & 8.00 & \text { 'married couple, spouses' } \\ \mathbf{1 1} & \text { kochana } & 7.0 & -1.42 & 4.99 & \text { 'loved, dear' } \\ \mathbf{1 2} & \text { ludzkość } & 8.0 & -3.67 & 4.79 & \text { 'humanity' } \\ \mathbf{1 3} & \text { lud } & 11.0 & -5.80 & 5.45 & \text { 'people' } \\ \mathbf{1 4} & \text { rodzice } & 90.0 & -7.53 & 12.14 & \text { 'parents' } \\ \mathbf{1 5} & \text { spojrzenie } & 11.0 & -11.38 & 4.77 & \text { 'look' } \\ \mathbf{1 6} & \text { poeta } & 8.0 & -13.40 & 3.47 & \text { 'poet' } \\ \mathbf{1 7} & \text { dusza } & 11.0 & -14.59 & 4.48 & \text { 'soul' } \\ \mathbf{1 8} & \text { matka } & 74.0 & -15.40 & 10.93 & \text { 'mother' } \\ \mathbf{1 9} & \text { para } & 7.0 & -18.15 & 2.64 & \text { 'couple' } \\ \mathbf{2 0} & \text { mąż } & 18.0 & -23.92 & 5.60 & \text { 'husband' } \\ & & & & \end{array}$


(13) Eng. love

Nominal Collocates

\begin{tabular}{|l|l|l|l|l|l|}
\hline$\#$ & Collocate & POS & A & TTEST & MI3 \\
\hline 1 & affair & $\mathrm{N} \%$ & 231.0 & 13.26 & 18.68 \\
\hline 2 & song & $\mathrm{N} \%$ & 76.0 & 5.86 & 14.10 \\
\hline 3 & bite & $\mathrm{N} \%$ & 29.0 & 4.73 & 12.77 \\
\hline 4 & story & $\mathrm{N} \%$ & 107.0 & 3.96 & 14.18 \\
\hline 5 & scene & $\mathrm{N} \%$ & 63.0 & 3.89 & 12.92 \\
\hline 6 & triangle & $\mathrm{N} \%$ & 11.0 & 2.15 & 8.43 \\
\hline 7 & potion & $\mathrm{N} \%$ & 5.0 & 1.98 & 7.82 \\
\hline 8 & nest & $\mathrm{N} \%$ & 14.0 & 1.97 & 8.69 \\
\hline 9 & poetry & $\mathrm{N} \%$ & 18.0 & 1.86 & 9.17 \\
\hline 10 & feast & $\mathrm{N} \%$ & 9.0 & 1.81 & 7.67 \\
\hline 11 & philtre & $\mathrm{N} \%$ & 3.0 & 1.71 & 9.49 \\
\hline 12 & tryst & $\mathrm{N} \%$ & 3.0 & 1.65 & 7.57 \\
\hline 13 & songs & $\mathrm{N} \%$ & 3.0 & 1.63 & 7.26 \\
\hline 14 & token & $\mathrm{N} \%$ & 7.0 & 1.58 & 6.92 \\
\hline 15 & shack & $\mathrm{N} \%$ & 3.0 & 1.37 & 5.45 \\
\hline 16 & rolle & $\mathrm{N} \%$ & 3.0 & 1.35 & 5.36 \\
\hline 17 & cheat & $\mathrm{N} \%$ & 3.0 & 1.31 & \\
\hline
\end{tabular}

\section{Final words}

In the process of uncovering the ways of approximate communication, the present study has employed both qualitative as well as a frequency-based research approach. It presents samples of a system of preferred rather than discreetly delineated meaning usage patterns in language that account for meaning approximation practices. In the cases of mapping of one conceptualization system inferred from language data in terms of form-meaning clusters on that of other ones, the study identifies Cultural Profiles inferred from the displacement of senses and the re-conceptualization types dominant across particular pairs of languages or language varieties as well as the patterns of meaning approximation and correspondence clusters with regard to intra- and inter-linguistic communication types. The extension of the resemblance tolerance measures is also observed from prototypical, more universal patterns, through culture-specific preferences, to more fully individualized and circumstantial equivalence conditioning. 


\section{References}

Austin, John 1962. How To Do Things with Words. Oxford University Press: Oxford.

Coulson, Seana 2001. Conceptual Blending. Frame-Shifting and Conceptual Blending in Meaning Construction. Cambridge: Cambridge University Press.

Doherty, Patrick, Łukaszewicz, Witold and Andrzej Szałas 2003. "Tolerance Spaces and Approximative Representational Structures." Proceedings of the $26^{\text {th }}$ German Conference on Artificial Intelligence, vol. 281 of LNAI. 1-15.

Gärdenfors, Peter 2004. Conceptual Spaces: The Geometry of Thought. Cambridge/London: Bradford/MIT Press.

Grice, Herbert Paul. 1975. Logic and conversation. In Peter Cole and Jerry L. Morgan (eds.), Syntax and Semantics 3: Speech Acts, 41-58. New York, London.

Gumperz, John J. 1982. Discourse Strategies. Cambridge: Cambridge University Press.

Gutt, Ernst-August. 1991. Translation and Relevance: Cognition and Context. Oxford: Basil Blackwell.

Hofstede, Geert 2001. Culture's Consequence: Comparing Values, Behaviors, Institutions, and Organizations AcrossNations, 2nd ed. Thousand Oaks, CA: Sage Publications

Jarniewicz, Jerzy 1992. A Few Remarks on Translating Contemporary Poetry. In Barbara Lewandowska-Tomaszczyk and Marcel Thelen (eds.), Translation and Meaning, Part 2, 191195. Maastricht: Rijkshogeschool Maastricht.

Katz, Jerrold J. 1978. Effability and Translation. In Franz Guenthner and Monica GuenthnerReutter (eds.), Meaning and Translation. Philosophical and Linguistic Approaches, 191-234. Reutter: New York.

Lakoff, George 1987. Women, Fire, and Dangerous Things: What Categories Reveal about the Mind. Chicago: University of Chicago Press.

Langacker, Ronald W. 1987/1991 Foundations of Cognitive Grammar, vols.1 and 2. Stanford: Stanford University Press.

Langacker, Ronald W. 2001. Discourse in Cognitive Grammar. Cognitive Linguistics 12(2). 143188.

Lewandowska-Tomaszczyk, Barbara 2015. Equivalence. In Łukasz Bogucki, Stanisław GoźdźRoszkowski and Piotr Stalmaszczyk (eds.), Ways to Translation, 11-54. Lodz: Lodz University Press.

Lewandowska-Tomaszczyk, Barbara 2013a. Approximative Communication in Translation. In Marcel Thelen and Barbara Lewandowska-Tomaszczyk (eds.), Translation and Meaning Part 9, 45-51. Maastricht: Zuyd University of Applied Sciences.

Lewandowska-Tomaszczyk, Barbara 2013b. Parameter Variability in Translational Approximation. In Marcel Thelen and Barbara Lewandowska-Tomaszczyk (eds.), Translation and Meaning Part 10, 27-37. Maastricht: Zuyd University of Applied Sciences.

Lewandowska-Tomaszczyk, Barbara 2012. Cognitive Corpus Analysis - A New Agenda for Contrastive Studies. Connexion - A Journal of Humanities and Social Sciences. 29-63.

Lewandowska-Tomaszczyk, Barbara 2012a. Approximative Spaces and the Tolerance Threshold in Communication. International Journal of Cognitive Linguistics 2(2). 2-19.

Lewandowska-Tomaszczyk, Barbara 2010. Re-conceptualization and the Emergence of Discourse Meaning as a Theory of Translation. In Barbara Lewandowska-Tomaszczyk and Marcel Thelen (eds.), Meaning in Translation, 105-148. Frankfurt am Main: Peter Lang.

Lewandowska-Tomaszczyk, Barbara 2007. Polysemy, prototypes, and radial categories. In Dirk Geeraerts and Hubert Cuyckens (eds.), Oxford Handbook of Cognitive Linguistics. Oxford: Oxford University Press. 139-169.

Lewandowska-Tomaszczyk, Barbara 1987. Conceptual Structure, Linguistic Meaning, and Verbal Interaction. Łódź: Łódź University Press. 
Lewandowska-Tomaszczyk, Barbara 1999. A Cognitive-interactional Model of Cross-linguistic Analysis: New Perspectives on 'tertium comparationis' and the Concept of Equivalence. In Barbara Lewandowska-Tomaszczyk (ed.), Cognitive Perspectives on Language, 53-76. Frankfurt am Main: Peter Lang.

Lewandowska-Tomaszczyk, Barbara 1985. On Semantic Change in a Dynamic Model of Language. In Jacek Fisiak (ed.), Historial Semantics. Historical Word-Formation, 297-323. Berlin: Mouton de Gruyter.

Lewandowska-Tomaszczyk, Barbara, John Osborne and Frits F. G. F. Schulte 2001. Foreign Language Teaching and Information and Communication Technology. Frankfurt am Main: Peter Lang.

Lewandowska-Tomaszczyk, Barbara and Paul A. Wilson 2015. It's a Date: Love and romance in time and space. In A. Ben-Ze'ev (ed.), Love \& Time, 1-41. Galilee. University of Haifa.

Lipsey, Richard G. and Kelvin Lancaster 1956. The General Theory of Second Best. Review of Economic Studies. 24 (1). 11-32.

Malinowski, Bronisław 1936. The Problem of Meaning in Primitive Languages. In Charles Kay Ogden and Ivor Armstrong Richards (eds.), The Meaning of Meaning [1923], Supplement I, 296-336. Kegan Paul.

Nida, Eugene 1992. Language and Culture. Talk given at the Facultat de Ciències Humanes, Traducciò i Documentaciò. University of Vic (May 1999).

Pęzik, Piotr 2014. Graph-Based Analysis of Collocational Profiles In V. Jesenšek and P. Grzybek (eds.), Phraseologie im Wörterbuch und Korpus ZORA 97, 227-243. Maribor, Bielsko-Biała, Budapest, Kansas, Praha: Filozofska fakuteta.

Sossinsky, Alexei B. 1986. Tolerance Space Theory and Some Applications. Acta Applicandae Mathematica 5(2). 137-167.

Sperber, Dan and Deirdre Wilson 1986. Relevance: Communication and Cognition. Oxford: OUP.

Svartvik, Jan (ed.) 1990. The London Corpus of Spoken English: Description and Research. Lund Studies in English 82. Lund: Lund University Press.

Whorf, Benjamin Lee 1956. Language, Thought and Reality: Selected Writings of Benjamin Lee Whorf. (ed. J. B. Carroll). Cambridge, Mass.: Technology Press of Massachusetts Institute of Technology.

Witt, Jessica K. and Dennis R. Proffitt 2007. Perceived Slant: A Dissociation between Perception and Action. Perception, Vol. 36. 249-257.

Wittgenstein, Ludwig 1921. Logisch-philosophische Abhandlung (Tractatus Logico-Philosophicus English translation 1922). Annalen der Naturphilosophie 14. Ed. Wilhem Ostwald.

Wittgenstein, Ludwig 1953. Philosophische Untersuchungen. (Philosophical Investigations; translated by G.E.M. Anscombe, 1953). Oxford: Blackwell.

\section{Corpora}

British National Corpus

A Corpus of English Conversation [CEC]

NKJP [www.nkjp.pl] National Corpus of Polish 